\title{
Evaluation of the stability of sandblasted, large-grit, acid-etched implants with tapered straight body design
}

\author{
Yong-Gun Kim, ${ }^{1,2}$ Kyu-Bok Lee ${ }^{2,3 *}$ \\ 'Department of Periodontology, School of Dentistry, Kyungpook National University, Daegu, Republic of Korea \\ ${ }^{2}$ Advanced Dental Device Development Institute, Kyungpook National University, Daegu, Republic of Korea \\ ${ }^{3}$ Department of Prosthodontics, School of Dentistry, Kyungpook National University, Daegu, Republic of Korea
}

Purpose: Implant surface modification and implant design are the principle targets for achieving successful primary stability. The aim of this study was to measure implant stability quotient (ISQ) values of sandblasted, large-grit, acid-etched (SLA) implants with tapered straight body design during the healing period, and to determine the various factors affecting implant stability. Materials and Methods: To measure implant stability, resonance frequency analysis (RFA) was performed in 26 patients (13 women and 13 men) with 44 SLA implants with tapered straight body design. Implant stability (ISQ values) was evaluated at baseline and healing abutment connection (12 weeks), and the correlations between RFA and insertion torque (IT), bone quality, and jawbone were determined. Results: The mean ISQ value of the implants was $69.4 \pm 10.2$ at the time of implant placement (baseline) and $81.4 \pm$ 6.9 at the time of healing abutment connection $(P<0.05)$. Significant differences were found between RFA and bone quality and between RFA and jawbone $(P<0.05)$. No significant differences were found between RFA and IT, insertion area, fixture diameter, and implant length $(P>0.05)$. Conclusion: ISQ values of SLA implants with tapered straight body design were high at baseline and healing abutment connection. It was concluded that SLA implants with tapered straight body design show improved primary and secondary stability, and that immediate or early loading may be applicable. (J Dent Rehabil Appl Sci 2018;34(2):80-8)

Key words: RFA (Resonance frequency analysis); ISQ (Implant Stability Quotient); SLA (Sandblasted, Large-grit, Acid-etched) implant

\section{Introduction}

Dental implants for functional recovery of missing dentition present high success rates if certain factors are considered. In particular, initial implant stability plays an important role for successful clinical outcome. Implant stability can be described at two different levels: primary and secondary. ${ }^{1}$ Primary stability, defined as the mechanical engagement immediately following implant installation, is an important factor for the success of the dental implant. Primary

\footnotetext{
*Correspondence to: Kyu-Bok Lee

Professor, Department of Prosthodontics, School of Dentistry, Advanced

Dental Device Development Institute, Kyungpook National University, 2177

Dalgubuldaero, Jung-gu, Daegu, 41940, Republic of Korea

Tel: +82-53-600-7674, Fax: +82-53-426-7661, E-mail: kblee@knu.ac.kr

Received: January 25, 2018/Last Revision: February 28, 2018/Accepted: March 2,

2018
} 
achieving a successful primary stability. ${ }^{5-7}$ Tapered implants enhance primary stability by inducing cortical bone compression in the weak bony area and dispersing the force to the surrounding bone, and are therefore beneficial in immediate implant placement. ${ }^{8}$

Currently, various diagnostic methods have been suggested to measure implant stability. Resonance frequency analysis (RFA) is a noninvasive and objective diagnostic method that measures implant stability using vibration, and is the principle of structural analysis. The first study using RFA as a method to measure stability was performed in 1996. ${ }^{9}$ Integration Diagnostics AB (Savedalen, Sweden) launched the Osstell ${ }^{\circledR}$ system in 2000, which has been adopted universally. The Osstell Mentor ${ }^{\circledR}$ system has an electronic tuning fork that automatically converts $\mathrm{kHz}$ to an Implant Stability Quotient (ISQ) value. The device is portable, and emits signals with a force of 5 $10 \mathrm{Ncm}$ that are repeated by a transducer connected directly to the implant. The resonance frequency is then calculated from the response signal.

RFA can reveal minor differences in implant stability and is generally performed to assess the efficacy of modification of implant surface, implant configuration, and thread design, which leads to improved and accelerated osseointegration. An RFA value between 1 and 100 is obtained (degree of stability ranging from lowest [1] to highest [100]). Recently, various factors influencing RFA assessments have been determined. The quality of the bone in which the implant was installed was the most significant factor; further, the implant length affected ISQ values to a certain degree over time. ${ }^{10}$ In addition, the lateral or occlusal positioning of the probe in relation to the peg did not affect ISQ values, while mesiodistal vs. buccolingual directional assessments appeared to be a point of slight variance. Therefore, two-directional measurement may reveal more precise information than one-directional readings.

The aim of this study was to monitor the stability of two-stage submerged, sandblasted, large-grit, acidetched (SLA) implants with tapered straight body design by applying RFA.

\section{Materials and Methods}

Ethical approval for this study was obtained from the Ethics Committee of Kyungpook National University Hospital (2015-08-022).

\section{Study population}

Twenty-six partially edentulous patients (13 women and 13 men, mean age: 54.5 years) participated in this study. The bone quality of the implant placement is described in Table 1.

Control of periodontal disease, when necessary, was achieved by motivation and oral hygiene instruction. If required, initial periodontal therapy consisted of root scaling and planing and periodontal surgery. Patient inclusion criteria were as follows: 1) unremarkable medical history, no known allergies, and no metabolic bone diseases; 2$)$ no heavy smoking $(<10$ cigarettes/day); and 3) adequate quantity and quality of native bone in order to achieve primary implant stability. Patient exclusion criteria were as follows: 1) severe bruxism or clenching habits; 2) untreated periodontitis or periapical pathology; and 3) heavy smoking (> 10 cigarettes/day).

\section{Clinical procedures}

\section{Implants}

A total of 44 implants (OneQ-SL implants, Dentis, Daegu, Korea) were placed according to standard procedure. The implants were double thread screw, tapered (upper) and straight (middle)-shaped titanium implants with four different diameters $(3.7,4.2$, 4.7 , and $5.2 \mathrm{~mm}$ ) and lengths ranging from 8 to 12 $\mathrm{mm}$. All implants had an SLA surface.

Table 1. Bone quality of implant placement

\begin{tabular}{lccc}
\hline & Anterior & Pre-molar & Molar \\
\hline Type I & 0 & 0 & 0 \\
Type II & 0 & 1 & 13 \\
Type III & 0 & 6 & 23 \\
Type IV & 0 & 0 & 1 \\
\multirow{2}{*}{ Total } & 0 & 7 & 37 \\
& & 44 & \\
\hline
\end{tabular}




\section{Surgery}

A drilling sequence and surgical procedure was applied, aiming for appropriate insertion torque (IT) and excellent initial stability. This was achieved using the following sequence: $1.8 \mathrm{~mm}$ guide drill, 2.0 $\mathrm{mm}$ twist drill, and $3.0 \mathrm{~mm}$ twist drill, for all sites. In cases where a wide implant was selected, the site was further prepared with 3.8 and $4.3 \mathrm{~mm}$ twist drills. Counter-sinking was performed to submerge the implant head in all bone qualities (Type 1, 2, 3, and 4) using the index described by Lekholm \& Zarb (1985). Implants were inserted at low speed (30 rpm). Mucoperiosteal flaps were sutured with non-resorbable nylon. Systemic antibiotics (Amocla $3 \times 375 \mathrm{mg}$ / day, Gunil, Seoul, Korea) and analgesics (Etodin $3 \times$ $200 \mathrm{mg} /$ day, Myungmoon, Daegu, Korea) were prescribed for seven days. Sutures were removed on day 14 post-surgery.

\section{Measurement parameters}

Clinical monitoring was performed at $1,4,8$, and 12 weeks post-surgery. Implant stability changes were evaluated over time by determination of total ISQ values at implant insertion (first OP) and healing abutment connection (second OP, 12 weeks), and the correlations between RFA and IT, bone quality, and jawbone were ascertained.

\section{Implant survival}

Clinical examination of the installed implants was performed at the second OP and two weeks after prosthesis delivery. Mobile implants were not regarded as failed implants and were not removed.

\section{Resonance frequency analysis (RFA)}

RFA was performed at implant insertion $(\mathrm{n}=44)$ and healing abutment connection $(n=44)$ by applying the Osstell ${ }^{\mathrm{TM}}$ Mentor $^{\circledR}$ (Integration Diagnostics AB, Göteborg, Sweden) (Fig. 1A). In each measurement, the implant fixture mounter and healing abutment were removed in order to access single implants. A transducer (Smartpeg ${ }^{\mathrm{TM}}$, Integration Diagnostics AB, Göteborg, Sweden) was connected to the implant (Fig. 1B).

Measurement using the frequency response ana- lyzer was performed four times from two different directions (e.g. from buccal and palatal directions). A radiographic examination was performed before and after surgery to obtain periapical radiographs and orthopantomograms (Fig. 2).
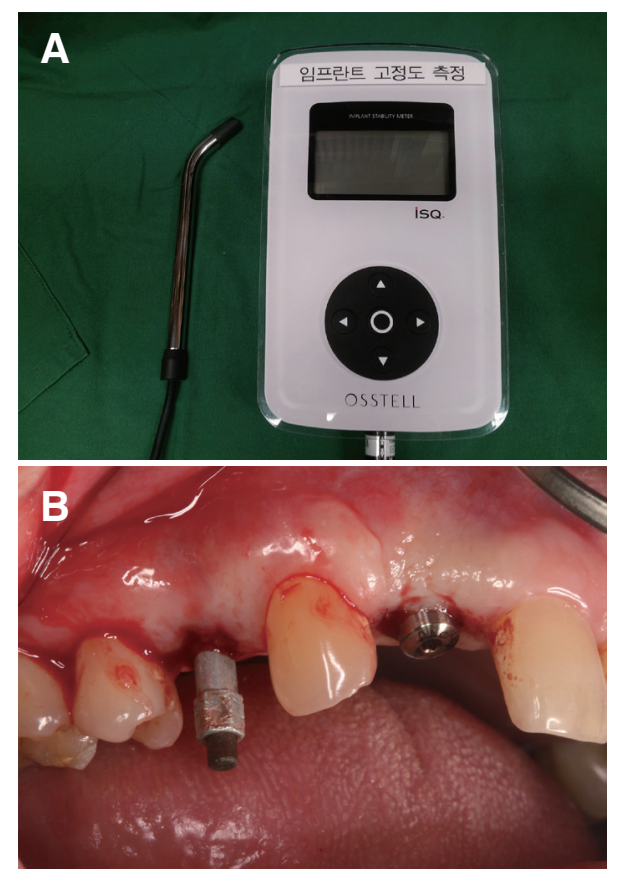

Fig 1. (A) Resonance frequency analyzer (Osstell Mentor ${ }^{\circledR}$ ), (B) Wireless transducer (Smartpeg ${ }^{\top M}$, Integration Diagnostics AB, Göteborg, Sweden) connected to the implant.
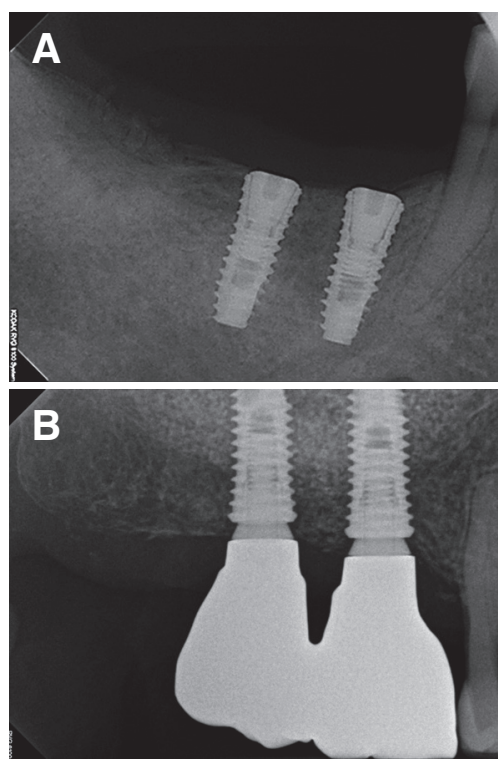

Fig. 2. Radiograph obtained soon after implant fixture installation (A) and final prosthesis setting (B). 


\section{Statistical analysis}

Statistical analyses were performed using the SPSS Statistics 23.0 package (IBM, Chicago, USA). Independent t-test and Levene homogeneity of variance test were performed. $P$ values of $<0.05$ were considered statistically significant.

\section{Results}

\section{Clinical observations}

A total of 44 implants were inserted in 26 patients. The post-operative healing was uneventful. The survival rate of the inserted implants was 100\% at healing abutment connection. No marginal bone loss or inflammation was observed.

\section{Implant stability changes over time (total ISQ values)}

The mean ISQ value of all the implants inserted was $69.4 \pm 10.2$ at the time of implant insertion and $81.4 \pm 6.9$ at healing abutment connection (Fig. 3).

A significant difference was found between the first and second OP $(P<0.05)$.

\section{Mean ISQ value for different variables}

The correlations between RFA and IT, bone quality, and jawbone at implant insertion and healing abutment connection were assessed. Significant positive correlations were found between RFA and bone

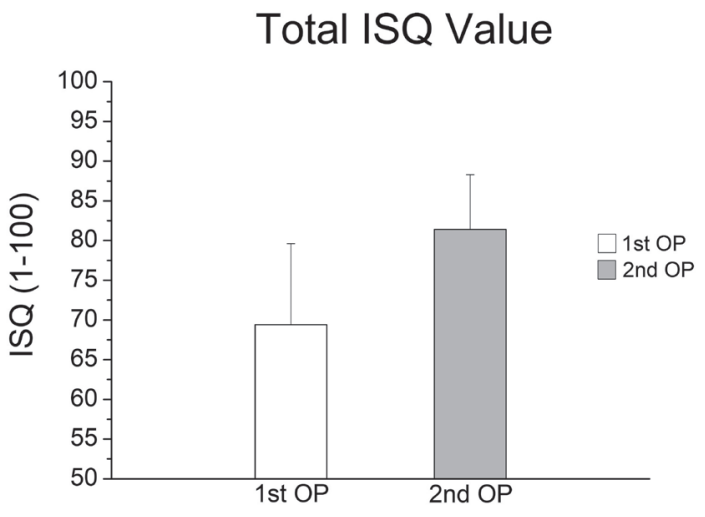

Fig. 3. Implant stability changes over time (first OP: week 0 , second OP: week 12). quality $(P<0.05$; Fig. $4 \mathrm{~A})$ and between RFA and jawbone $(P<0.05$; Fig. 4B). No significant correlations were found between RFA and IT or RFA and insertion area $(P>0.05$; Fig. 4C, 4D). No significant differences were found between RFA and fixture diameter or RFA and implant length (Fig. 5A, 5B).

ISQ values measured at three ITs $(25,30$, and 35 $\mathrm{Ncm})$ were higher at the second OP $(25 \mathrm{Ncm}: 83.4$ \pm 5.3 ; $30 \mathrm{Ncm}: 79.5 \pm 7.3)$ than at the first OP (25 Ncm: $71.5 \pm 11.3 ; 30 \mathrm{Ncm}$ : $67.3 \pm 8.7$ ) (Fig. 6A). ISQ values of type II bone were higher than those of type III at the first OP (type II: $78.6 \pm 5.2$; type III: $65.6 \pm 9.1$ ) and second OP (type II: $87.0 \pm 2.2$; type III: $78.5 \pm 6.7 ; P<0.05$ ) (Fig. 6B). Additionally, ISQ values of the mandible were higher than those of the maxilla at the first OP (mandible $74.8 \pm 9.7$; maxilla: $64.5 \pm 8.3$ ) and second OP (mandible: 85.4 \pm 3.6; maxilla: $77.1 \pm 8.8$ ) (Fig. 6C).

\section{Discussion}

Östman et al. ${ }^{11}$ have suggested the inclusion criterion of ISQ values for immediate loading of implant. They reported low failure rates when using ISQ 60 as an inclusion criterion for immediate loading implants in maxillae and posterior mandibles, with values above ISQ 65 indicative of immediate loading. ${ }^{11}$ In this study, it was shown that sandblasted and acidetched implants with tapered straight body design achieved good primary stability at implant insertion, yielding ISQ values indicative of a favorable response to immediate loading (mean $69.4 \pm 10.2$ ). This suggests that sandblasted and acid-etched implants with tapered straight body design have a suitable implant thread design, body configuration, and surgical protocol to achieve primary stability for immediate loading.

For secondary stability (i.e. biocompatibility) of sandblasted and acid-etched implants with tapered straight body design, the RFA measurement was performed at healing abutment connection. The mean ISQ value of all implants was increased by $17 \%$ at implant insertion $(81.4 \pm 6.9)$. These ISQ values were higher than those reported in previous studies using the same clinical protocol. ${ }^{10,12-15}$ This indicates that sandblasted and acid-etched implants with ta- 
A

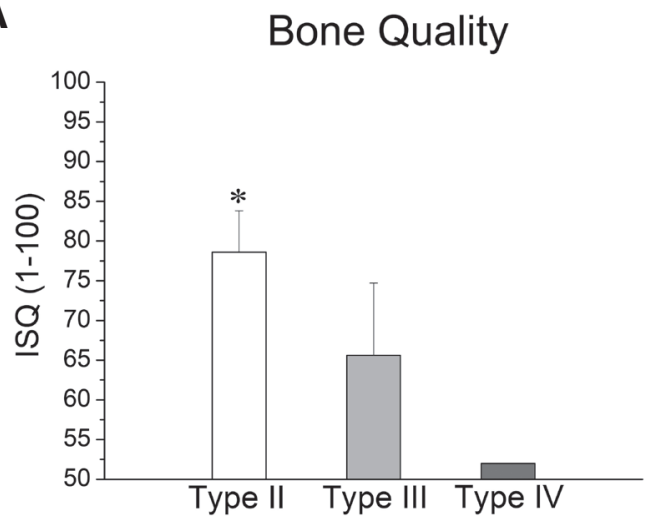

C

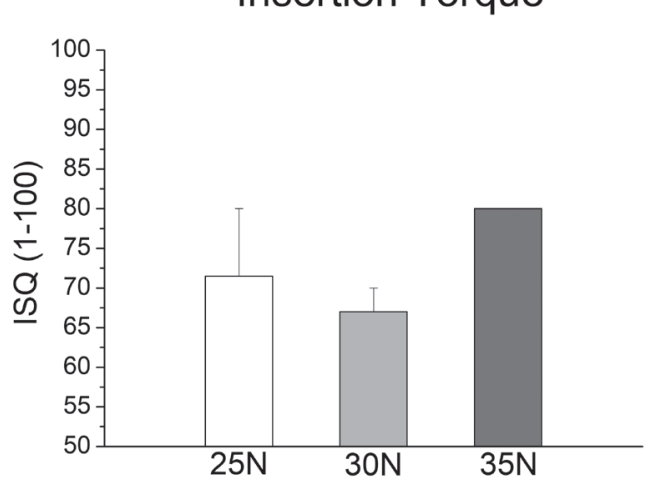

B

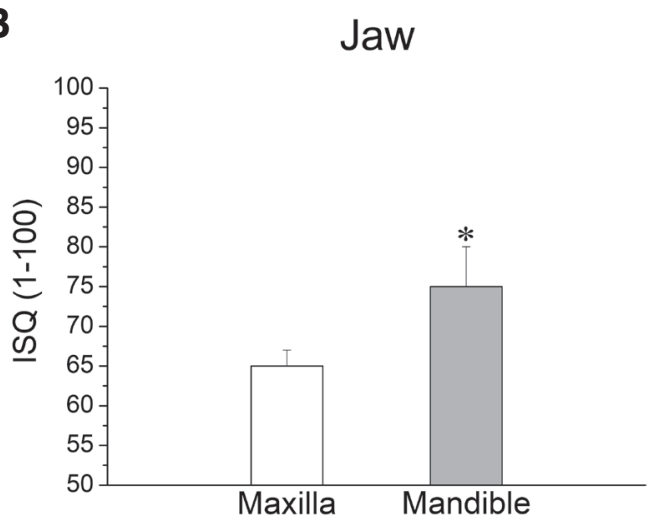

D

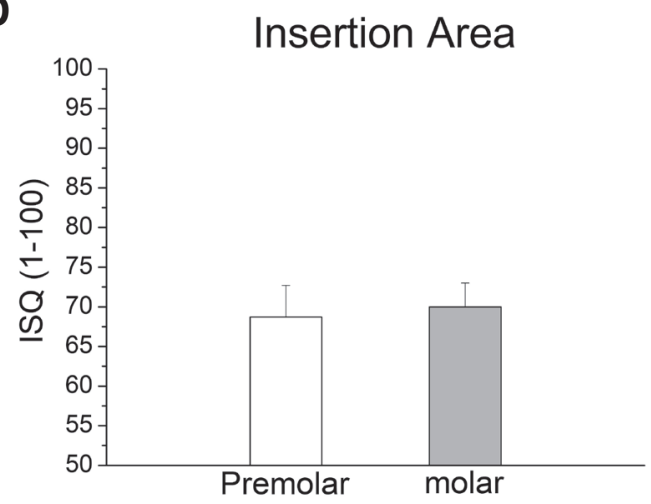

Fig. 4. Mean ISQ values for different variables I (immediately after implant, first OP). (A) Bone quality, (B) Jawbone, (C) IT, (D) Insertion area. Significant positive correlations were found between RFA and bone quality and between RFA and jawbone $(* P<0.05)$. No significant correlations were found between RFA, IT, and insertion area $(P>0.05)$.

A

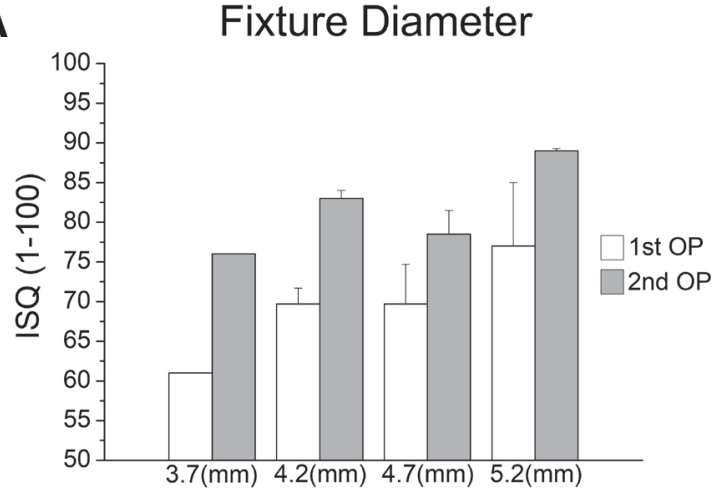

B

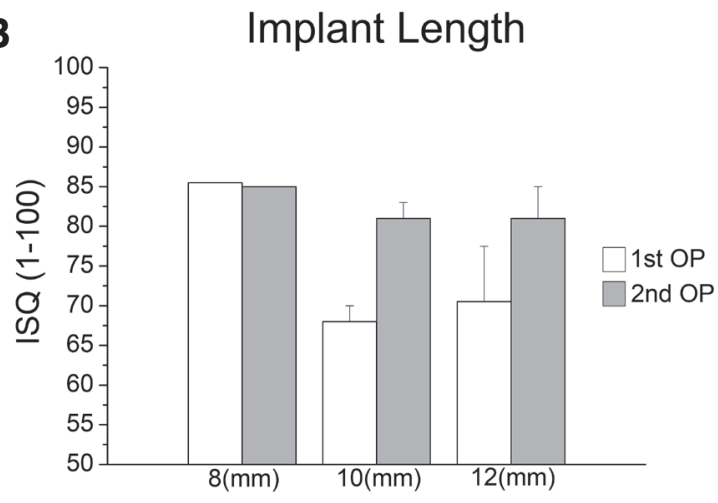

Fig. 5. Mean ISQ values for different variables II. (A) Fixture diameter, (B) Implant length. No significant correlations were found between RFA and fixture diameter or between RFA and implant length $(P>0.05)$. 

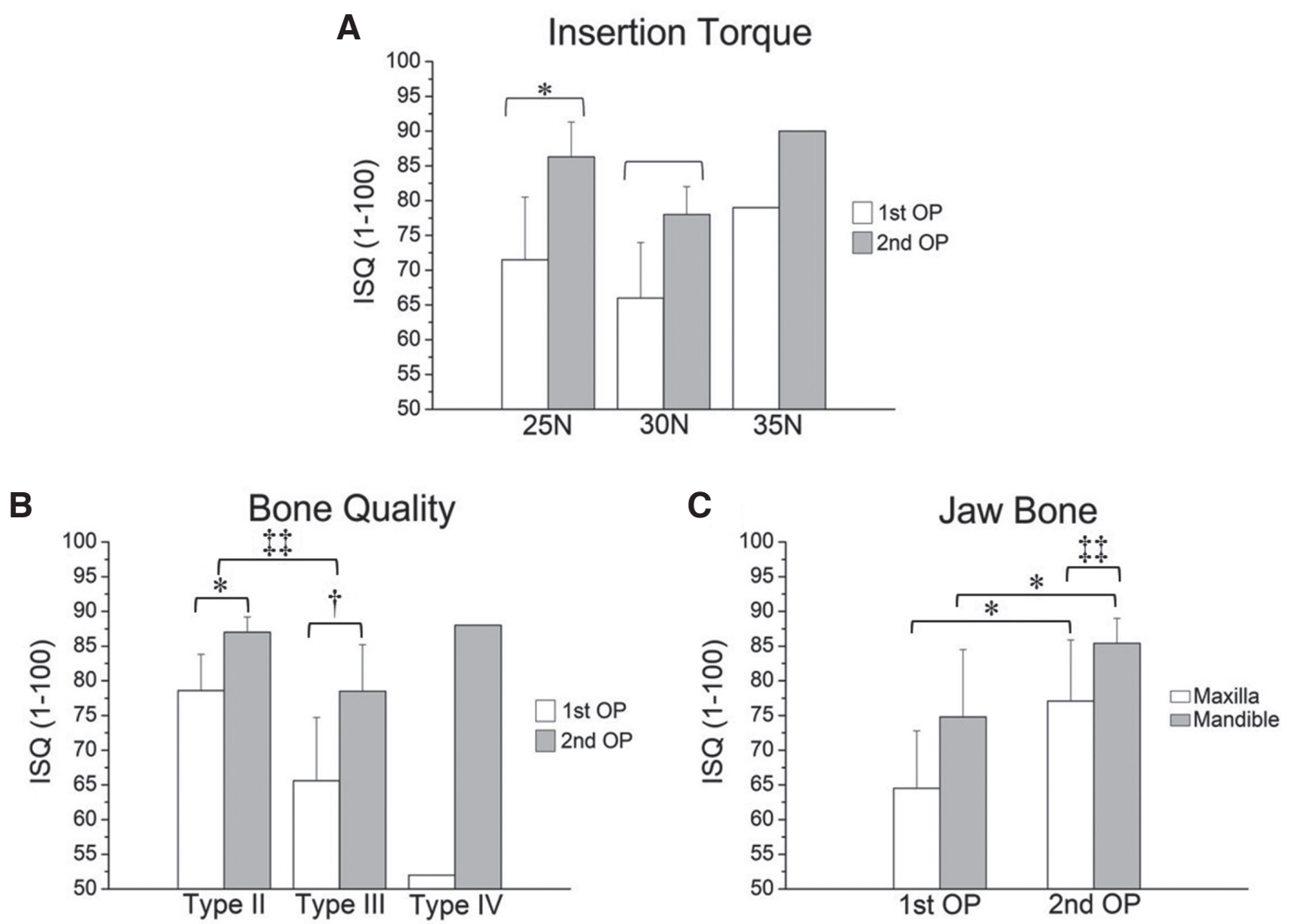

Fig. 6. Implant stability changes over time. (A) IT, * correlation between the mean ISQ values of the first and second $\mathrm{OP}$ at an IT of $25 \mathrm{Ncm}$; + correlation between mean ISQ values of the first and second OP at an IT of $30 \mathrm{Ncm}$. (B) Bone quality, * correlation between the mean ISQ values of the first and second OP on type II bone; ${ }^{\dagger}$ correlation between the mean ISQ values of the first and second OP on type III bone; ‡¥ Significantly different ISQ values between type II and type III bone at the second OP. (C) Jawbone, * correlation between the mean ISQ values of the first and second OP in the maxilla $(P<0.05) ;+$ correlation between the mean ISQ values of the first and second OP in the mandible $(P<0.05)$; $¥ \ddagger$ correlation between the mean ISQ values of the maxilla and mandible at the second OP $(P<0.05)$.

pered straight body design present an optimized SLA surface for improved osseointegration and are more osteoblast-compatible than the previous titanium surface modifications. Moreover, we can conclude that good initial stability of implants contributes to secondary stability and bone remodeling.

Several studies have suggested that IT values at 25 - $45 \mathrm{Ncm}$ could avoid adverse micro-movement (threshold level between 50 and $100 \mu \mathrm{m}$ ) under loading, thus allowing the osseointegration healing process to commence. ${ }^{16,17}$ It is clear that a high IT provides the clinician a degree of certainty regarding the initial stability of the implant. However, an excessively high IT could increase overpressure to the surrounding bone and lead to micro-fracture of the bone, with resorption in the cortical area and a delayed healing process. In this study, the mean IT values of sandblasted and acid-etched implants with tapered straight body design were $28 \mathrm{Ncm}$. Therefore, the surgical protocol for implant insertion and the implant design were suitable for primary stability. There was no significant difference in ISQ values between $25 \mathrm{Ncm}$ and $30 \mathrm{Ncm}(P>0.05)$.

Lai et al. ${ }^{18}$ reported that primary stability is affected by bone quality. Their study on 104 ITI SLA implants demonstrated significantly higher ISQ values for implants in type I bone than in type IV bone. In addition, Turkyilmaz et al. ${ }^{19}$ found a strong correlation 
between bone density and ISQ values. The highest ISQ value $(36.1 \mathrm{kHz})$ in this study was for an implant inserted into type I bone; in contrast, an ISQ value of $9.9 \mathrm{kHz}$ was for an implant in type IV bone by Huang et al. ${ }^{20}$ In this study, a significant correlation between bone quality and ISQ value at the time of implant insertion was observed for type II bone and type III bone $(P<0.05)$. There was also a significant difference between bone quality and ISQ value at the time of the second OP $(P<0.05)$. In this study, an ISQ value of 52 was obtained at the time of implant insertion into type IV bone, and an ISQ value of 88 was obtained at healing abutment connection. These results suggest that the stability of implants inserted in weak bones can be improved over time. This is consistent with a report by Friberg et al. ${ }^{21}$

Bischof et al. ${ }^{22}$ stated that implant length, position, and diameter did not affect primary stability. Regarding implant diameter and length and RFA, Horwitz et al. ${ }^{23}$ reported no correlation between fixation length and RFA; however, they suggested that larger implant diameters were associated with higher ISQ values. The current study is consistent with their results.

Several studies ${ }^{9,24,25}$ reported that the use of longer and wider implants increased primary stability due to the increased bone-to-implant contact surface area. However, our findings did not corroborate this observation.

Bone quality and implant stability are lower in the maxilla than in the mandible. According to several reports, ${ }^{23,26,27}$ primary stability is higher in the mandible than in the maxilla, a result also observed in the present study $(P<0.05) .{ }^{28}$ In addition, Nedir et al. ${ }^{29}$ reported that the value of ISQ was $<60$ in the maxillary implants and $>60$ in the mandibular implants. Regarding implant position (premolar and molar), we found no differences from the data published by Balleri et al. ${ }^{27}$

\section{Conclusion}

Within the limitations of this study, we conclude that SLA implants with tapered straight body design show improved primary and secondary stability, and immediate or early loading may be applicable.

\section{Acknowledgements}

The clinical studies were supported by DENTIS Inc. (Daegu, Korea).

\section{References}

1. Meredith N. Assessment of implant stability as a prognostic determinant. Int J Prosthodont 1998;11: 491-501.

2. Cochran DL, Schenk RK, Lussi A, Higginbottom FL, Buser D. Bone response to unloaded and loaded titanium implants with a sandblasted and acidetched surface: a histometric study in the canine mandible. J Biomed Mater Res 1998;40:1-11.

3. Brunski JB. Biomechanical factors affecting the bone-dental implant interface. Clin Mater 1992;10: 153-201.

4. Sennerby L, Roos J. Surgical determinants of clinical success of osseointegrated oral implants: a review of the literature. Int J Prosthodont 1998;11: 408-20.

5. Klokkevold PR, Nishimura RD, Adachi M, Caputo A. Osseointegration enhanced by chemical etching of the titanium surface. A torque removal study in the rabbit. Clin Oral Implants Res 1997;8:442-7.

6. Piattelli A, Manzon L, Scarano A, Paolantonio M, Piattelli M. Histologic and histomorphometric analysis of the bone response to machined and sandblasted titanium implants: an experimental study in rabbits. Int J Oral Maxillofac Implants1998;13:805-10.

7. Yeo IS, Han JS, Yang JH. Biomechanical and histomorphometric study of dental implants with different surface characteristics. J Biomed Mater Res B Appl Biomater 2008;87:303-11.

8. Glauser R, Sennerby L, Meredith N, Rée A, Lundgren A, Gottlow J, Hämmerle CH. Resonance frequency analysis of implants subjected to immediate or earlyfunctional occlusal loading. Successful vs. failing implants. Clin Oral Implant Res 2004;15:428-34.

9. Meredith N, Alleyne D, Cawley P. Quantitative determination of the stability of the implant-tissue interface using resonance frequency analysis. Clin 
Oral Implants Res 1996;7:261-7.

10. Sim CP, Lang NP. Factors influencing resonance frequency analysis assessed by Osstell mentor during implant tissue integration: I. Instrument positioning, bone structure, implant length. Clin Oral Implants Res 2010;21:598-604.

11. Ostman PO, Hellman M, Wendelhag I, Sennerby L. Resonance frequency analysis measurements of implants at placement surgery. Int J Prosthodont 2006;19:77-83.

12. Rowan M, Lee D, Pi-Anfruns J, Shiffler P, Aghaloo T, Moy PK. Mechanical versus biological stability of immediate and delayed implant placement using resonance frequency analysis. J Oral Maxillofac Surg 2015;73:253-7.

13. Guler AU, Sumer M, Duran I, Sandikci EO, Telcioglu NT. Resonance frequency analysis of 208 Straumann dental implants during the healing period. J Oral Implantol 2013;39:161-7.

14. Boronat López A, Balaguer Martínez J, Lamas Pelayo J, Carrillo García C, Peñarrocha Diago M. Resonance frequency analysis of dental implant stability during the healing period. Med Oral Patol Oral Cir Bucal. 2008;13:E244-7.

15. Rabel A, Köhler SG, Schmidt-Westhausen AM. Clinical study on the primary stability of two dental implant systems with resonance frequency analysis. Clin Oral Investig 2007;11:257-65.

16. Trisi P, Perfetti G, Baldoni E, Berardi D, Colagiovanni M, Scogna G. Implant micromotion is related to peak insertion torque and bone density. Clin Oral Implants Res 2009;20:467-71.

17. Barone A, Alfonsi F, Derchi G, Tonelli P, Toti P, Marchionni S, Covani U. The Effect of Insertion Torque on the Clinical Outcome of Single Implants: A Randomized Clinical Trial. Clin Implant Dent Relat Res 2016;18:588-600.

18. Lai HC, Zhuang LF, Zhang ZY. Stability of implants placed in different bone types. Zhonghua Kou Qiang Yi Xue Za Zhi 2007;42:292-3.

19. Turkyilmaz I, Sennerby L, McGlumphy EA, Tözüm TF. Biomechanical aspects of primary implant stability: a human cadaver study. Clin Implant Dent Relat Res 2009;11:113-9.

20. Huang HM, Lee SY, Yeh CY, Lin CT. Resonance frequency assessment of dental implant stability with various bone qualities: a numerical approach. Clin Oral Implants Res 2002;13:65-74.

21. Friberg B, Sennerby L, Meredith N, Lekholm U. A comparison between cutting torque and resonance frequency measurements of maxillary implants. A 20-month clinical study. Int J Oral Maxillofac Surg 1999;28:297-303.

22. Bischof M, Nedir R, Szmukler-Moncler S, Bernard JP, Samson J. Implant stability measurement of delayed and immediately loaded implants during healing. Clin Oral Implants Res 2004;15:529-39.

23. Horwitz J, Zuabi O, Peled M. Resonance frequency analysis in immediate loading of dental implants. Refuat Hapeh Vehashinayim 2003;20:80-8.

24. Polizzi G, Rangert B, Lekholm U, Gualini F, Lindström H. Brånemark System Wide Platform implants for single molar replacement: clinical evaluation of prospective and retrospective materials. Clin Implant Dent Relat Res 2000;2:61-9.

25. Calandriello R, Tomatis M, Vallone R, Rangert B, Gottlow J. Immediate occlusal loading of single lower molars using Brånemark System WidePlatform TiUnite implants: an interim report of a prospective open-ended clinical multicenter study. Clin Implant Dent Relat Res 2003;5:74-80.

26. Barewal RM, Oates TW, Meredith N, Cochran DL. Resonance frequency measurement of implant stability in vivo on implants with a sandblasted and acid-etched surface. Int J Oral Maxillofac Implants 2003;18:641-51.

27. Balleri P, Cozzolino A, Ghelli L, Momicchioli G, Varriale A. Stability measurements of osseointegrated implants using Osstell in partially edentulous jaws after 1 year of loading: a pilot study. Clin Implant Dent Relat Res 2002;4:128-32.

28. Lazzara R, Siddiqui AA, Binon P, Feldman SA, Weiner R, Phillips R, Gonshor A. Retrospective multicenter analysis of $3 i$ endosseous dental implants placed over a five-year period. Clin Oral Implants Res 1996;7:73-83.

29. Nedir R, Bischof M, Szmukler-Moncler S, Bernard JP, Samson J. Predicting osseointegration by means of implant primary stability. Clin Oral Implants Res 2004;15:520-8. 


\section{테이퍼드 직선형 SLA 임플란트의 안정성 평가}

\section{김용건 ${ }^{1,2}$, 이규복 $2,3 *$}

${ }^{1}$ 경북대학교 치의학전문대학원 치주과학교실

${ }^{2}$ 경북대학교 첨단치과의료기기개발연구소

${ }^{3}$ 경북대학교 치의학전문대학원 치과보철학교실

목적: 임플란트 표면의 특성과 임플란트 디자인은 성공적인 초기 고정을 얻는데 중요한 변수이다. 이 연구의 목적은 치유 기간 동안 테이퍼드 직선형 디자인을 가진 SLA (Sandblasted and Acid-etched) 임플란트의 ISQ (Implant Stability Quotient) 값을 측정하고 임플란트의 안정성에 미치는 영향을 평가하는 것이다.

연구 재료 및 방법: 임플란트의 안정성을 측정하기 위하여 26명의 환자(여자 13 명, 남자 13 명)의 44 개 임플란트에 대한 자기공명주파수분석(Resonance Frequency Analysis)을 실시하였다. 골질 및 골량에 대한 임상적 평가는 Lekholm \& Zarb (1985)의 기준에 따라 시행하였다. 시간경과에 따른 임플란트 안정성변화(총 ISQ 값)를 고정체 식립 시 그리고 12 주후 치유지대주 연결 시 측정하고 RFA와 식립토크, RFA와 골질, RFA와 상, 하악골 사이의 상관관계를 평가하였다.

결과: 임플란트의 평균 ISQ값은 임플란트 식립 당시(기준선) $69.4 \pm 10.2$, 치유지대주연결에서(두번째수술) $81.4 \pm 6.9$ 였 다 $(P<0.05)$. RFA와 골질, RFA와 상하악골 사이에 유의한 차이가 있었다 $(P<0.05)$. RFA와 식립토크, 식립부위, 고정 체 직경, 임플란트 길이 사이에는 유의한 차이가 없었다 $(P>0.05)$.

결론: 본 연구의 제한된 범위내에서 테이퍼드 직선형 디자인을 가진 SLA 임플란트의 ISQ값은 고정체 식립시와 치유지대 주 연결 시 모두 높은 값을 보였다. 따라서 테이퍼드 직선형 디자인을 가진 SLA 임플란트는 초기안정성 및 2차 안정성을 향상시킬 수 있으며, 즉시 또는 초기하중을 적용할 수 있을것으로 사료된다.

(구강회복응용과학지 2018;34(2):80-8)

주요어: 자기공명주파수분석; 임플란트 안정성 지수; SLA (sandblasted, large-grit, acid-etched) 임플란트

*교신저자: 이규복

(41940) 대구광역시 중구 달구벌대로 2177 경북대학교 치의학전문대학원 치과보철학교실

Tel: 053-600-7674 | Fax: 053-426-7661 | E-mail: kblee@knu.ac. kr

접수일: 2018년 1월 25일 | 수정일: 2018년 2월 28일 | 채택일: 2018년 3월 2일 